\title{
Report on the 19th annual Gathering in Biosemiotics in Moscow
}

\section{Arran Gare ${ }^{1}$}

The 19th annual Biosemiotics Gathering that took place on 1-5 July 2019, was hosted by the Philosophy Faculty of Lomonosov Moscow State University. That it was hosted by a philosophy faculty rather than a science faculty, and that it was hosted in Russia, are both significant. Biosemiotics is a challenge to mainstream biology, still struggling to gain acceptance despite the work of a great many researchers and a great many publications, along with nineteen annual biosemiotics gatherings. But it is much more than this, and this accounts for why gaining acceptance is so difficult. In Thomas Kuhn's terminology, it is revolutionary science, not normal science. It has not yet achieved a consensus on philosophical issues, basic concepts and methods that allows its practitioners to get on with the business of puzzle solving and forget about philosophy. More importantly, it is a challenge not only to mainstream assumptions in biology but also a challenge to deeper assumptions about what counts as science, what is science, and what is the relationship between science and other cultural fields. It is also a challenge to the broader culture of modernity with its tacit acceptance of Cartesian dualism, manifest in the division between the sciences and the humanities. Therefore, it is entirely appropriate for this biosemiotics gathering to be hosted by a philosophy faculty.

Russia has been home to a long tradition of radical scientific and cultural thought, much of it attempting to advance beyond Cartesian dualism, even before the Bolshevik revolution. In the 1920s there was an explosion of radical ideas in the sciences and humanities going beyond reductionist materialism, vitalism and Idealism. Despite adverse conditions from 1930 onwards, research programmes originating at this time not only survived but advanced and had a major influence outside the Soviet Union. Until the field was suppressed in the

1 Swinburne University of Technology, Melbourne, Australia; e-mail: agare@swin.edu.au. 
1930s, the Soviet Union led the world in research in ecology. Work on symbiosis by Lev Berg and others later influenced Lynn Margulis's notion of symbiogenesis. Vladimir Vernadsky developed the notions of the biosphere and the noosphere, precursors to James Lovelock's Gaia theory and Jesper Hoffmeyer's notion of the semiosphere. Ludwig von Bertalanffy's systems theory was influenced by Alexander Bogdanov's tektology and the theoretical biology movement in Britain led by C. H. Waddington and Joseph Needham developed the notion of the morphogenetic field which originated with the Ukrainian biologist Alexander Gurwitsch. Lev Vygotsky began a major research programme in psychology and education, which was promoted in the West by Jerome Bruner. Vygotsky's notion of scaffolding was taken up in biosemiotics by Jesper Hoffmeyer. The linguistic theorist Roman Jakobson, who left Russia in 1920, was a major influence on the Prague and Copenhagen schools of semiotics, French structuralism and also influenced the Hungarian American Thomas Sebeok. Sebeok, who embraced the work of C. S. Peirce, later forged links with the Estonian semioticians, most importantly, Juri Lotman who had founded the Tartu-Moscow School of Semiotics. Sebeok rediscovered the work of Jakob von Uexküll, and called for a synthesis of semiotics and biology. This coincided with a revival of theoretical biology in the Soviet Union, and biosemiotics was taken up vigorously by the Tartu-Moscow School of Semiotics. This was enthusiastically adopted in Moscow by Alexej Sharov, who has organized two conferences on biosemiotics. Stanislav Bushev, the main organizer of the gathering and a Philosophy Faculty member of Lomonosov Moscow State University, wrote his dissertation on "Biosemiotics as paradigm for formation of theoretical biology" (Bushev 2009) and has continued work on biosemiotics from the perspective of philosophy of science.

The first two speakers at the gathering were Donald Favareau and Kalevi Kull. Favareau has in the past provided one of the most comprehensive studies of the historical background to biosemiotics (along with John Deely) and edited its most important anthology (Favareau 2010). His writings have been essential to defining the broader significance and goals of biosemiotics, and integrating different strands of thought in biosemiotics to advance it as a major international research programme. It is through Favareau's history that the significance of biosemiotics can be appreciated as not only a development within science but a challenge to Cartesian thought, echoing Deely's suggestion that European civilization would have developed very differently if the work on semiotics of João Poinsot, the 17th-century Portuguese philosopher who anticipated many of Peirce's ideas, had defined its direction rather than Descartes. While Favareau largely presupposed this history in his lecture, focusing instead on disagreements between major figures within the biosemiotics community (in this case, Terrence Deacon and 
Frederik Stjernfelt) on the basic issue of understanding Peirce's trichotomy of icon, index and symbol, Favareau's presence and prominent position as first speaker indicated the respect accorded to his broad claims for biosemiotics.

Kalevi Kull was influenced by the Tartu-Moscow School of Semiotics which was established between 1964 and 1970 while centrally involved in the revival of theoretical biology in the Soviet Union in the 1970s. Embracing Sebeok's vision of integrating biology and semiotics based on combining the ideas of Peirce and Jakob von Uexküll, he was one of the founders of biosemiotics. He facilitated its advance by the rigour of his thinking and his ability to integrate a vast range of other ideas into its research programme. Along with the Danish biosemioticians (with other major centres of biosemiotics research located in Czechia and the USA and smaller centres elsewhere), Kull is now at the core of the world biosemiotics movement and at the core of defining its direction. It was Kull who first proposed these biosemiotics gatherings. His work has been particularly important for the development of ecosemiotics, although his contributions go well beyond this area. His contribution in this introductory speech was to sum up the present state of biosemiotics, indicating what had been achieved and what are the problems lying ahead. Specifically, he grappled with boundary problems, looking at the conditions for semiosis and considering whether, given the parallels between biosemiotics and Harald Atmanspacher's 'weak quantum theory', this could allow for the application of a quantum theory analogy to biosemiotics. While he accepted the effort to see analogies between quantum phenomena and mental phenomena, he insisted that semiotics could not be reduced to physics. Semiosis should be seen as an emergent phenomenon. His presentation could be seen as providing a reference point for those committing themselves to biosemiotics.

Most of the subsequent presenters tacitly assumed that biosemiotics has succeeded in establishing itself as a respectable research programme, that it is almost normal science, although giving room for new developments and work on its foundations. On this assumption presenters grappled with significant problems of showing how the research programme can be extended to new frontiers, for instance finding the minimal level at which there is semiosis, considering bacteria and slime moulds (Oscar Castro Garcia), or treating proteins' behaviour from a semiotic and pragmatic point of view as the equivalent of speech acts, grappling with the problem of what, then, is the dynamical object and the immediate object, and what type of sign is protein behaviour (Ludmila Lacková and Dan Faltynek). In other presentations, difficult cases were re-examined, such as the origins of language (Jeremiah Scalia) or characterizing the different levels of semiosis from DNA to human language and everything in-between. Jeremy Sherman explained how Terrence Deacon's emergent constraint theory, somewhat similar to the 
generative constraint theories put forward by Howard Pattee and Stanley Salthe who participated in many of the early biosemiotics discussions, could provide firm foundations for biosemiotics and extend its influence. In a similar vein, biosemiotics was defended by Arran Gare from the charge by Marcello Barbieri that it is not really science by showing how Robert Rosen's mathematics and relational biology could explain the triadic nature of semiosis as characterized by Peirce, along with final causes, as the product of processes which are components of each other without being reducible to each other, while in turn, Rosen's work can be characterized as a development of, and defended through, Peirce's semiotic logic (Gare 2019).

Different problematic aspects of biosemiotics were revisited, such as the problem of adequately accounting for agency, how groups of cells diffuse signals (Victoria Alexander), dealing with the emergence of subjects along with objects (David Decker), explaining the emergence of meaning (Mark Pharoah), and dealing with the hard-problem of consciousness (Szura Bruni). The work of Walker Percy, a largely ignored semiotician influenced by Peirce, was examined by John Schumann to highlight the existence of non-material phenomena such as concepts, ideas, idealizations, ideologies etc., and terms that go along with these, such as confusion, truth, democracy, law etc. These, Percy argued against behaviourists, are made possible by the triadic relation between symbol, object, and interpreter, giving the symbol a quasi-identity with the object, but in another mode of existence. This other mode of existence is the source of mind, meaning, consciousness, art and religion. A number of presenters grappled with issues raised by ecology. Morten Tønnessen examined biosemiotic relationality to show how it is required to understand ecological complexity. This, and other presentations on ecology, also grappled with environmental and political problems. Yogi Hendlin suggested that the current plethora of global political problems facing us are due to the endosemiotic activity of micro-organisms occupying the partly-human but parasitized decision-makers now dominating the world. Sanita Fejzić proposed radically new political paths to deal with ecological and political issues based on biosemiotics.

There were also re-examinations of core concepts, such as Jakob von Uexküll's notion of the umwelt (David Decker) and Gregory Bateson's notion of information (Jaime Cárdenas-García). Tyler Bennett argued for a reunification of Peircean and structuralist semiotics, again highlighting the differences between different biosemioticians and examining the diverse characterizations of signs. Similarly, Israel Chávez Barreto related Hjelmslev's theory to Deacon's theory of emergent dynamics. Some efforts were made to open new perspectives into Peircean biosemiotics, such as Tommi Vehkavaara suggesting a place should be given to first- as well as third-person perspectives. 
These are the papers that took what is now the mainstream Peircean-Uexküll conception of biosemiotics as their point of departure and reference point. Other contributions were only loosely related to this mainstream or were not connected with it at all, although they could have been. The problem of individuation was addressed by Vefa Karatay and Yagmur Denizhan, who drew attention to the work of the French philosopher Gilbert Simondon who accounted for it in terms of internal resonance. Individuation is a major problem for Peircean biosemiotics because Peirce did not supply an adequate account of individuation, but it was left to others to work out how to integrate Simondon's work with Peircean biosemiotics. The problem of emotion and its relation to words for emotion were examined by Pauline Delahaye, although no particular semiotic theory was utilized.

Russians offered different perspectives on biosemiotics. One distinctively Russian contribution was made by Leonid Zhukov, situating biosemiotics as one of an array of diverse disciplines related to gnoseology. 'Gnoseology' is a term widely used in Russia that has almost dropped from language in the West, being replaced by 'epistemology'. However, gnoseology encompasses much more than this, and as Zhukov pointed out, can include not only work in philosophy of knowledge and science, but the open and non-linear systems theories of Ludwig von Bertalanffy and Ilya Prigogine, autopoiesis theory, cybernetics and informatics, psychoanalysis, and even aspects of theoretical physics. Zhukov characterized such work as 'object-processing recursion', that is, a cyclical process of self-production inevitably involving description of description, emphasizing theory, as opposed to objective science. Gnoseology, Zhukov suggested, can account for how organisms direct their evolution. Zhukov also drew attention to the work on whether cybernetics can be applied to sign systems embedded in biological organisms, conducted by Alexander Levich at Moscow State University in the 1970s. Other Russians utilized the ideas of structuralist semioticians rather than Peircean semiotics, or treated semiosis as little different from the conventional notion of information feedback, although this was not always the case. Ivan Fomin for instance proposed a semiotic model based on Peirce's later work to characterize the building blocks that emerge in processes of biological, social, cognitive and cultural development. In considering the problem of agency, Alexej Sharov examined the differences between enactivism, associated with the notion of autopoiesis, and biosemiotics, showing how these might be reconciled through a more genuine biosemiotic notion of agency. Work taking place in Russia on problems with different approaches than those used elsewhere were also examined. For instance, Mihail Ilyin described a way of reinvestigating the similarities and differences between human language and genetic expression 
and Nikita Shklovskij-Kordi and colleagues utilized structuralist semiotics to describe a semiotic system of genetic language. Attention was also drawn by Ekaterina Velmezova to another overlooked semiotician, the Soviet anti-Darwinist evolutionary biologist and geographer Lev Berg. In the 1920s Berg defended the theory of orthogenesis, that there is a direction to evolution, combining this with mutationism, to develop the theory of 'nomogenesis'. According to this, evolution is driven by mass mutations that are not random but are directed by internal and external factors so that they have a high probability of being adapted to their environments. Symbiosis, requiring semiosis, is central, and natural selection, Berg argued, plays a very limited role in evolution. New theoretical advances were also proposed, such as Anton Sukhoverkhov's effort to combine the semiosis of evolution with process approaches and theories of non-genetic inheritance, arguing that these form complementary perspectives. Alexander Spirov described work in complexity theory engaging with embryology and opened the possibility of combining semiotics with the concept of morphogenetic fields, linking current biosemiotics research to theoretical biologists such as $\mathrm{C}$. H. Waddington. This link has been suggested by Western biosemioticians, including Joanna Raczaczek and Favareau, but not extensively developed. New fields were also offered, such as Anastasia Kolmogorova and colleagues' analysis of the sentiment of texts, including fascination.

While such work is contributing to the advance of biosemiotics, as noted, biosemiotics is not normal science. As Favareau, and Tyler Bennett in another presentation, pointed out, there is no agreement on fundamental concepts even by those who have seen themselves as followers of Peirce. Kull, strongly influenced by Peirce, has not simply accepted Peirce's philosophy. In an earlier work he showed that Peirce had himself abandoned the idea cherished by some Peirceans that the fundamental laws of physics can be accounted for as the outcome of habit formation, and at this conference he pointed out that the famous triad of sign, object and interpretant has to be modified if it is to be applied to primitive forms of life because these do not cognize immediate 'objects' in their umwelten. Thomas Kuhn argued that normal science is largely defined by its exemplars, that is, exemplary achievements that all students in the discipline know about and take as models to emulate. Unravelling the code for the production of proteins from DNA could be taken as such an exemplar, yet even this achievement was questioned by John Collier at the 18th annual Gathering in Biosemiotics. Therefore code biology, while important, is not at the centre of biosemiotics, and its main proponent, Marcello Barbieri, has broken with the biosemioticians. Another work that could be taken as an exemplar is Terrence Deacon's The Symbolic Species (1997), but as noted, Deacon's interpretation of Peirce and use of core concepts differs 
from other major Peircean biosemioticians. Imré Lakatos argued that research programmes are characterized by hard cores of assumptions that are adhered to above all else and are the foundation and reference point for all research. Newton's three laws of motion exemplify such a hard core (with his exemplary achievement being to have explained by means of these laws the elliptical orbit of Mars). The core of Darwinian biology is that evolution occurs through random variation in progeny and selection of the fittest. It is difficult to specify exactly the hard core of the biosemiotics research programme. It could be that semiosis is a defining feature of life, but even this is not accepted by all biosemioticians, and there is yet to be complete agreement on defining semiosis and signs. There are good grounds for taking Peirce's insight that semiosis is essentially triadic as the hard core in terms of which all semiotic processes and all other semiotic theories should be understood and ultimately explained, but again, not all biosemioticians accept this.

Biosemiotics is a long way from being accepted into the fold of conventional science, with subjects in biosemiotics standard within courses in biology, as biochemistry is now. In fact there is no guarantee that biosemiotics as a distinct research programme and subject in biology will survive the retirement of its founding members. There has been a proliferation of specialized research programmes and highly specialized journals over the last two decades, and it is highly unlikely that all of these, or even most of them, will survive. There are two major journals in biosemiotics, but there were three: Semiotics, Evolution, Energy, and Development (S.E.E.D.) ceased publication in 2006.

So, biosemiotics is and should be recognized by its adherents as revolutionary science. This is how it has been understood by the Danish biosemioticians, with Jesper Hoffmeyer's book Signs of Meaning in the Universe (Hoffmeyer 1996) functioning as its manifesto. Advancing biosemiotics faces major difficulties because success would mean transforming not only the field of biology but the field of science and its relation to the rest of culture, most importantly, the humanities as Paul Cobley in Cultural Implications of Biosemiotics (Cobley 2016) and Wendy Wheeler in The Whole Creature (Wheeler 2006), following Sebeok, have argued. It really involves transforming our understanding of ourselves and our place in nature; and the ways people understand themselves and their place in nature form the foundations of civilizations. This is what the scientific revolution of the 17th century, and to a lesser extent, Darwinian evolutionary theory, biochemistry, molecular biology and genetics in the 19th and 20th centuries achieved. Advancing revolutionary science is not only an intellectual struggle, but at the same time a political struggle for the conditions to develop, disseminate and to act on the basis of new ways of thinking. It involves forging alliances inside 
and outside intellectual life to overcome opposition. Because people challenging prevailing research programmes are almost always in relatively weak positions, their efforts invariably involve struggling to maintain the institutional conditions to pursue the truth rather than serving those with power. However, what counts as truth is also contested, and it is impossible to define truth formally in a way that is beyond questioning. This is one reason why revolutionary science always involves developing historical narratives to reveal the assumptions and failures of ideas being challenged, to identify precursors whose work has been unjustly neglected, to identify potentially allied research programmes that can be integrated to form a more effective challenge, and to orient its adherents in the struggle to create the future. While defenders of current orthodoxies have a vested interest in ignoring philosophical questioning and historical narratives that can expose taken-for-granted assumptions, often held in place by prevailing disciplinary boundaries, philosophical and historical work to reveal and question deep assumptions and to develop and integrate alternative frameworks of concepts is a necessary component of revolutionary science. Since biosemiotics is a very radical challenge to mainstream science, philosophical and historical work involving not only meeting objections to the research programme, but looking for weaknesses and constantly challenging whatever ideas are put forward is required. This is necessary to achieve greater coherence and greater force as a challenge to current orthodoxies, and to facilitate highly focussed work which might achieve the breakthroughs that force doubters to take the research programme seriously.

While the diversity of views presented at the gathering provided material for bringing out such philosophical and historical issues, discussion of these was largely absent at the formal sessions, although they were discussed informally. One indication of the lack of specific focus on philosophical issues was the absence of debate over the use of the word 'information'. The paper examining and defending Bateson's definition of information as 'a difference that makes a difference, the definition which has been embraced in the past by biosemioticians to align the notion of information with biosemiotics, showed how it incorporates and transcends Shannon's notion of information. This is important for biosemiotics. However, this was not presented as a defence of biosemiotics against informatics, and in other presentations 'information' was used uncritically in a more conventional way without acknowledging that mainstream scientists regard biosemiotics as unimportant because Shannon's notion of information and cybernetics alone can deal adequately with the phenomena focussed on by biosemioticians. Living beings, including humans, are for them nothing but information-processing cyborgs. 
More importantly, the bigger question of why it is important to oppose mainstream science on such matters did not appear to be a live issue in formal discussions. This requires a broader historical perspective such as Favareau has offered, seeing biosemiotics as a response to Cartesian dualism that underlies almost all the major philosophical and cultural problems since the 17th century. Apart from technical issues, these include the question of what is the meaning of life, or whether it has any meaning. This issue, which was raised in the 18th annual Biosemiotics Gathering in Berkeley, is at the core of the struggle between mainstream science and the humanities, with the sciences implying that the world is devoid of meaning and life is nothing but a struggle for survival between different arrangements of matter, and the humanities defending values at least in human life. Favareau's broader perspective is also required to understand fully the different strands within biosemiotics, with the code biologists and structuralist semioticians pre-eminently concerned to be scientific, while the biohermeneuticists such as Anton Markoš and Sergej Chebanov, more aligned with the humanities, are most concerned to oppose the nihilistic view of the world defended by mainstream science and to do full justice to the reality and significance of sentient life. The agreement to embrace the title 'biosemiotics' rather than biohermeneutics or semantic biology and to give a central place to Peircean semiotics should be seen in this context as a judgement that Peircean concepts, and particularly Peirce's characterization of semiosis, developed as part of his profound work on the logic of science, has the potential to integrate all work on the semiotics of biological processes and all opposition to mainstream science within science, and also opposition coming from the humanities, and then to spearhead the challenge to transform mainstream science and advance the humanities. Granting a place in research to both analysis and synthesis, it appears to have the most potential to overcome Cartesian dualism.

The relation between the different strands within biosemiotics should be understood not only in relation to the opposition between the sciences and the humanities, but also to the current state of the science and the humanities. The humanities, originating in the Florentine Renaissance and concerned to revive and inspire people to live by the values and ideals of Ancient Greece and Republican Rome, survived Descartes and Newton but were more fundamentally challenged by Darwinian evolutionary theory presenting humans as just clever animals, especially as Darwinian evolutionary theory was streamlined into the synthetic theory of evolution with the development of genetics, biochemistry and molecular biology. The end point was to claim that, as Richard Dawkins put it, living beings, including ourselves, are nothing but gene machines, machines for reproducing strings of DNA. Cartesian dualism gave way to the reductionist 
monism of Thomas Hobbes and the economists, mind was treated at best as an epiphenomenon, and the humanities went into decline. The last stand by the humanities was taken in the mid-20th century with the development of hermeneutic and existential phenomenology, with French philosophers taking the lead. In France this challenge failed, and to defend their status, humanities scholars turned to structuralism, gaining support for doing so from structuralist mathematicians. These structuralists claimed that they could provide the humanities with scientific credentials they now needed to maintain respect within the academic community. They also failed. The conflict between structuralism and hermeneutics engendered poststructuralism, which, led by Jacques Derrida and Michel Foucault and embraced in Anglophone countries, challenged not only humanist values, but the value accorded to scientific truth, thereby eliminating the last vestige of noble values upheld by the scientific enterprise.

In this context, the most promising avenue for defending the humanities and their values was to claim intrinsic value for all life, not as a subjective preference but as objectively defensible. The crisis in the humanities coming at a time of accelerating ecological destruction threatening not only most terrestrial species but the future of humanity spurred the development of philosophical biology, antireductionist theoretical biology and then biosemiotics, each supporting radical ideas in ecology. These held out the last hope for upholding the humanities and humanistic human sciences, and avoiding the political consequences of denying value to living beings except as instruments.

It is not only the humanities that are in crisis, however. Current science is also in crisis. The scientific world-view was never monolithic. Mainstream Darwinian theory was opposed not only by religious fundamentalists, but by biologists who pointed out the inconsistencies and deficiencies in the orthodox view, often drawing on the work of Darwin himself to do this. Apart from reductionist scientists being unable to account for sentience or consciousness, on the basis of blind variation and selection they could only promise explanations for the generation of biological forms observed in the development of embryos and for the complexity of multicellular forms of life that have evolved. The promise is unconvincing, and Jerry Fodor and Massimo Piattelli-Palmarini (2010) argued in What Darwin Got Wrong that Darwinian evolutionary theory has no validity. On investigation, the notions of genes and genetic information were also found to be largely incoherent, as El-Hani, Queiroz and Emmeche (2009) argued in Genes, Information, and Semiosis. There are alternatives. Embryology has been the base for an alternative tradition of biology from Karl Ernst von Baer to Conrad $\mathrm{H}$. Waddington and Brian Goodwin, and their challenge is now reinforced by biosemiotics. 
Support for such alternative research programmes in biology has come from the physical sciences, particularly physics, where deep assumptions that led scientists and even Kant to identify the advance of science with reductionist explanations, were brought into question, even by Kant himself. Friedrich Schelling in particular, influenced by Kant's dynamic theory of matter and his work on biology, called for and sketched a speculative physics to replace Newtonian science on the grounds that Newtonian physics is inconsistent with the existence of life and consciousness. With the development of field theories of electricity, magnetism and light, the development of thermodynamics, the development of relativity theories and quantum theory and then, more recently, the development of complexity theory, this project of replacing Newtonian physics has been partly realized, although not entirely. These developments in turn have been utilized to support opposition to mainstream reductionist biology. These opposing traditions of biology have been described by Anton Markoš (2002) in Readers of the Book of Life, which can usefully be read in conjunction with Favareau's history of biosemiotics. The most important advances in the tradition of theoretical biology were brought together in the four conferences on theoretical biology organized by Waddington in the late 1960s and early 1970s, the proceedings of which were published in four volumes. In the final volume of this, Waddington argued that biology needs to draw on linguistics to advance it further, referring to Howard Pattee, Jean Piaget and Jerome Bruner in this regard. Participants in these conferences, including Stuart Kauffman and Brian Goodwin as well as Pattee, have subsequently made significant contributions to the development of biosemiotics. Their work would suggest the way science is developing provides further support for the work of the biosemioticians.

However, science is not developing smoothly. It is riddled with problems and inconsistencies between major partially successful research programmes, for instance, quantum theory and the general theory of relativity. Theoretical physics has made very little progress for decades. And scientific progress appears increasingly problematic. After producing nuclear weapons that came close to destroying civilization, technological progress now appears to be concentrating power in the hands of power elites as never before, and locking humanity into a trajectory of global ecological destruction. The mass production of scientific papers generated by the publish-or-perish syndrome has generated so much shoddy science that whatever advances are made are likely to be ignored. Quantum theory now has so many different versions and interpretations it is difficult to count them. One of the most challenging problems in quantum theory is the measurement problem and how to deal with it. It was this problem that led the theoretical physicist Howard Pattee to argue that quantum theory could 
explain how molecules become messages, moving from physics to theoretical biology to interpret quantum theory. Echoing Schelling, more and more physicists are now looking to theoretical biology as a reference point for defining the direction for physics. Recently, the theoretical physicist and Nobel laureate Brian Josephson has suggested that it is only through the development of biosemiotics, utilizing the notion of scaffolding as developed by Hoffmeyer, that the problem of measurement will be properly dealt with and a coherent cosmology arrived at (Josephson 2019).

So, in light of the impact a fundamentally flawed culture of modernity has had on the world, the state of the humanities and the sciences and the role that biosemiotics is being called upon to play in dealing with all these crises, it would appear that some participants in the biosemiotics gathering might not have fully appreciated the significance of biosemiotics and are not taking themselves and their research programme seriously enough. Holding the 19th biosemiotics gathering in Russia, bringing new researchers into the programme, has the potential to alter this. As I have already pointed out, Russia has been a major source of ideas in the tradition of anti-reductionist thinking in science and in the humanities. Aleksander Bogdanov and his brother-in-law, Anatolij Lunacharskij, the first Commissar for Culture and Education in the Soviet Union, called for the creation of a new culture, incorporating all that was best in past cultures. Lunarcharskij was a playwright with a strong interest in the arts, but also promoted the development of science and had a particular interest in, and major role in, developing ecology. This movement for a new culture helped promote the explosion of creative activity in the 1920s that began a number of research traditions. These, including the work of Bakhtin and his circle, which fed into and influenced the Tartu-Moscow School of Semiotics as well as developments in the sciences, have provided a counter tradition to reductionist thinking in the sciences and nihilistic developments in the humanities. It is this complex of traditions, which survived the Stalinization of science and culture, that inspired Sebeok and provided the receptive environment for Sebeok's ambition to fuse semiotics with biology. This whole tradition is now being integrated into biosemiotics, and through biosemiotics, could be brought to fruition, providing the foundations for the kind of radical transformation of culture, including science, that Lunacharskij was promoting. On the basis of their contributions to biosemiotics in the past and this biosemiotics gathering we can hope Russians will play a major role in this.

The formal proceedings of conferences and the formal discussions are only a part of the intellectual life of international conferences, and the hosts of this gathering provided ideal conditions for informal discussions. It was within these that some of the problems facing the development of biosemiotics and 
directions for advancing it more effectively were considered. The value of such discussions is that a much wider range of concerns can be aired, with people coming from different disciplines, research traditions and countries having different perspectives. Biosemiotics appears to have been much more difficult to establish in my home country, Australia, than other countries, with most of those promoting it in Australia scattered. However, this is also the case with a range of research programmes that challenge mainstream thought in Australia. As an historically oriented philosopher of science and environmental philosopher originally inspired by C. H. Waddington and Joseph Needham to establish the Joseph Needham Centre for Complex Processes Research before embracing biosemiotics, the difficulty in gaining support for such research has coloured my own outlook. Waddington and Needham's extremely promising research programme lost out to molecular biology and the synthetic theory of evolution. Reflecting on the difficulties facing theoretical biologists, Waddington defined the problem as overcoming COWDUNG, the conventional wisdom of the dominant group. Historical work in science has revealed this to be a recurring problem for what are later acknowledged by everyone to have been superior research programmes. I see biosemiotics continuing the struggle against COWDUNG, and in relation to biosemiotics, my own deepest concern is to work out how to wage this struggle successfully. To some extent, this report is a continuation of and also a report on some of these further discussions.

\section{References}

Bushev, Stanislav 2009. Biosemiotika kak paradigma formirovaniya teoreticheskoj biologii.

Dissertation. Moscow: Moscow State University. [Бушев, Станислав Александрович 2009. Биосемиотика как парадигма формирования теоретической биологии. Диссертация. Москва: МГУ.]

Cobley, Paul 2016. Cultural Implications of Biosemiotics. (Biosemiotics 15.) Dordrecht: Springer. Deacon, Terrence 1997. The Symbolic Species: The Co-evolution of Language and the Human Brain. London: Penguin.

El-Hani, Charbel Niño; Queiroz, João; Emmeche, Claus 2009. Genes, Information, and Semiosis. (Tartu Semiotics Library 8.) Tartu: Tartu University Press.

Favareau, Donald (ed.) 2010. Essential Readings in Biosemiotics: Anthology and Commentary.

(Biosemiotics 3.) Dordrecht: Springer.

Fodor, Jerry A.; Piattelli-Palmarini, Massimo 2010. What Darwin Got Wrong. London: Profile Books.

Gare, Arran 2019. Biosemiosis and causation: Defending biosemiotics through Rosen's theoretical biology, or, integrating biosemiotics and anticipatory systems theory. Cosmos and History 19(1): 31-90. 
Hoffmeyer, Jesper 1996. Signs of Meaning in the Universe. Bloomington: Indiana University Press.

Josephson, Brian D. 2019. The physics of mind and thought. Activitas Nervosa Superior: The Journal for Neurocognitive Research 61(1/2): 86-90.

Markoš, Anton 2002. Readers of the Book of Life: Contextualizing Developmental Evolutionary Biology. Oxford: Oxford University Press.

Wheeler, Wendy 2006. The Whole Creature: Complexity, Biosemiotics and the Evolution of Culture. London: Lawrence \& Wishart. 